Estuarine, Coastal and Shelf Science

September 2016, Volume 179, Pages 226-235

http://dx.doi.org/10.1016/j.ecss.2015.09.009

http://archimer.ifremer.fr/doc/00280/39123/

(c) 2015 Elsevier Ltd. All rights reserved

\title{
Why is Asari (= Manila) clam Ruditapes philippinarum fitness poor in Arcachon Bay: a meta-analysis to answer?
}

\author{
De Montaudouin X. ${ }^{1,{ }^{*}}$, Lucia M. ${ }^{1}$, Binias C. ${ }^{1}$, Lassudrie M. ${ }^{2}$, Baudrimont M. ${ }_{1}{ }^{1}$, Legeay A. ${ }^{1}$, \\ Raymond N. ', Jude-Lemeilleur F. ${ }^{1}$, Lambert C. ${ }^{2}$, Le Goïc N. ${ }^{2}$, Garabetian F. 1, Gonzalez P. . 1 , \\ Hégaret Helene ${ }^{2}$, Lassus Patrick ${ }^{3}$, Mehdioub W. ${ }^{3}$, Bourasseau L. ${ }^{1}$, Daffe G. ${ }^{1}$, Paul-Pont I. ${ }^{1}$, \\ Plus Martin ${ }^{4}$, Do V.T. ', Meisterhans G. ', Mesmer-Dudons N. ', Caill-Milly Nathalie ${ }^{5}$, \\ Sanchez Florence ${ }^{5}$, Soudant P. ${ }^{1}$
}

\footnotetext{
${ }^{1}$ Université de Bordeaux, UMR EPOC CNRS, Station Marine d'Arcachon, 2 rue du Pr Jolyet, 33120 Arcachon, France

${ }^{2}$ LEMAR, Laboratoire des Sciences de l'Environnement Marin (LEMAR), UMR6539. Institut Universitaire Européen de la Mer (IUEM), Université de Bretagne Occidentale (UBO) Place Nicolas Copernic, 29280 Plouzané, France

${ }^{3}$ Ifremer, Laboratoire Phycotoxines, BP 21105, 44311 Nantes Cedex3, France

${ }^{4}$ Ifremer, LER/AR, Quai du Commandant Silhouette, 33120 Arcachon, France

${ }^{5}$ Ifremer, Laboratoire Ressources Halieutiques Aquitaine RBE/HGS/LRHA, 1 allée du Parc Montaury, 64600 Anglet, France

*Corresponding author : X. de Montaudouin, email address : x.de-montaudouin@epoc.u-bordeaux1.fr

Magali.Lucia@npolar.no ; Malwenn.Lassudrie@univ-brest.fr ; m.baudrimont@epoc.u-bordeaux1.fr ; a.legeay@epoc.u-bordeaux1.fr ; n.raymond@epoc.u-bordeaux1.fr ; f.jude@epoc.u-bordeaux1.fr ; Christophe.Lambert@univ-brest.fr ; Nelly.LeGoic@univ-brest.fr ; f.garabetian@epoc.u-bordeaux1.fr ; p.gonzalez@epoc.u-bordeaux1.fr ; Helene.Hegaret@univ-brest.fr ; Walid.Medhioub@ifremer.fr ; l.bourasseau@epoc.u-bordeaux1.fr ; quillemine.daffe@u-bordeaux1.fr ; ika.paulpont@univ-brest.fr ; Martin.Plus@ifremer.fr ; n.mesmer-dudons@epoc.u-bordeaux1.fr ; Nathalie.Caill.Milly@ifremer.fr ; Florence.Sanchez@ifremer.fr ; Philippe.Soudant@univ-brest.fr
}

\begin{abstract}
:
Asari (=Manila) clam, Ruditapes philippinarum, is the second bivalve mollusc in terms of production in the world and, in many coastal areas, can beget important socio-economic issues. In Europe, this species was introduced after 1973. In Arcachon Bay, after a decade of aquaculture attempt, Asari clam rapidly constituted neo-naturalized population which is now fished. However, recent studies emphasized the decline of population and individual performances. In the framework of a national project (REPAMEP), some elements of fitness, stressors and responses in Arcachon Bay were measured and compared to international data (41 publications, 9 countries). The condition index $(\mathrm{Cl}=\mathrm{flesh}$ weight/shell weight) was the lowest among all compared sites. Variation in average Chla concentration explained $30 \%$ of variation of $\mathrm{Cl}$ among different areas. Among potential diseases, perkinsosis was particularly prevalent in Arcachon Bay, with high abundance, and Asari clams underwent Brown Muscle Disease, a pathology strictly restricted to this lagoon. Overall element contamination was relatively low, although arsenic, cobalt, nickel and chromium displayed higher values than in other ecosystems where
\end{abstract}


Asari clam is exploited. Finally, total hemocyte count (THC) of Asari clam in Arcachon Bay, related to the immune system activity, exhibited values that were also under what is generally observed elsewhere. In conclusion, this study, with all reserves due to heterogeneity of available data, suggest that the particularly low fitness of Asari clam in Arcachon Bay is due to poor trophic condition, high prevalence and intensity of a disease (perkinsosis), moderate inorganic contamination, and poor efficiency of the immune system.

\section{Highlights}

Asari clams characteristics are compared among 9 countries through 41 references. $>30 \%$ of condition index variation is explained by chlorophyll a concentration. $>$ Chla and diseases explain most of Asari clam poor fitness in Arcachon Bay.

Keywords: Ruditapes philippinarum, Condition index, Perkinsus, Brown Muscle Disease, Element contamination, Immune system, Arcachon Bay

\section{Introduction}

Mollusc bivalves display a strong phenotypic plasticity, i.e. their environment modulate their population dynamics, including reproduction, recruitment, growth and mortality ( de Montaudouin, 1996, Newell, 2004 and Peterson and Black, 1987). Factors involved in individual growth are the best understood. Most bivalves are suspension feeders and their growth performance is strongly related to food availability ( Suh and Shin, 2013 and Watanabe et al., 2009) alongside the role played by temperature ( Fan et al., 2007 and Nam Han et al., 2008). For 
intertidal bivalves, food availability directly depends on immersion time and plankton quantity (and quality). However many factors may disrupt the relation between trophic source and specific consumers. Competition with other suspension-feeders has been welldocumented (Fukumori et al., 2008; Troost et al., 2009). Many medium-scale experiments highlighted intra- and interspecific competition, mainly focusing on growth performance (Brock, 1980; Kamermans et al., 1992; Peterson, 1982; Ramón, 1996), but also on condition index (de Montaudouin and Bachelet, 1996) which represents the ratio between the flesh weight and the shell weight (or volume). At larger scale, the strategy rather consisted in assessing the capacity of the environment to sustain bivalve production ("carrying capacity") (Dame and Prins, 1998; McKindsey et al., 2006; Sarà and Mazzola, 2004).

Finally, co-occurring abiotic and biotic factors can impair bivalve fitness. Parasites are omnipresent in bivalve communities (de Montaudouin et al., 2000; Gam et al., 2008; Thieltges and Reise, 2007). Clades like trematodes are prevalent in bivalves and rather considered as population regulators, although they may induce mass mortality (Jonsson and André, 1992; Thieltges, 2006). In shellfish aquaculture, infectious diseases represent the first cause of mortality and can be related to few protozoan genuses (Perkinsus, Bonamia, Marteilia, Haplosporidium), bacteria and virus such as Vibrio and herpes virus, respectively (Morley, 2010; Rowley et al., 2014). Harmful algal bloom is another preoccupying source of stress impairing bivalve fitness, in interaction or not with other factors, e.g. parasitism (Lassudrie et al., 2014). Bivalve communities, exploited or not, are mainly distributed along coastal systems where anthropogenic pressure can also exert strong constraints. As filterfeeders, bivalves are efficient bioaccumulators (Byrne and O'Halloran, 2001; Carroll et al., 2009; Lehtonen et al., 2006; Verlecar et al., 2006). All kinds of pollutants may perturb bivalve physiology and impair their performances (Guerlet et al., 2010; Kim et al., 2008; Mearns et al., 2012). 
The world production of marine bivalves in 2011 is ca. 12.8 million tons/year, when pooling fisheries and aquaculture statistics (FAO, 2014). Three groups of bivalves (oysters, mussels and clams) represented ca. $78 \%$ of the total aquatic production (FAO, 2014). None are preserved from episodic or chronic crisis (Carnegie, 2005). Factors responsible of mass mortality are often identified, pathogen or drastic environmental changes for instance. Conversely, the responsibility of bad performances (deficit of growth, condition index, recruitment) is much more difficult to identify, due to the diversity of factors interacting within their habitat (as described above).

The Asari clam (Ruditapes philippinarum) originates from Indo-Pacific waters. Since 1930, it has been introduced into different part of the world (Flassch and Leborgne, 1992). In Europe, R. philippinarum was primarily introduced in France for culture purposes in 1972 and later to England, Spain and Italy (Flassch and Leborgne, 1992). Within a few years, this bivalve established neo-natural populations in most southern European countries. In France, Arcachon Bay population ranked first in terms of biomass and exploited stock (Sanchez et al., 2014). The exploited stock was steadily declining (1159 t in $2008 v s 723 \mathrm{t}$ in 2012) causing a crisis for fishermen and a drop of fishing licences. Deficit of growth, condition index and recruitment were quantified (Dang et al., 2010b). Among possible factors involved in these bad performances, diseases were evoked although their prevalence and intensity cannot explain alone this chronic crisis (Binias et al., 2014b; Dang et al., 2013; Dang et al., 2008).

Between 2009 and 2013, in the framework of a French Ministry of Environment program (LITEAU 3, REPAMEP Project), a pluridisciplinary team monitored several parameters related to R. philippinarum biology in Arcachon Bay. Fitness of R. philippinarum in this Bay (and environmental factors) was compared to Asari clam fitness (and environmental factors) described in the literature elsewhere in the world where this species is exploited in order to 
detect environmental factors impairing or ameliorating Asari clam fitness in the Bay of Arcachon.

Two major problems were encountered. Firstly, most studies dealt with one type of factor (e.g. parasitism or chemical contaminants or harmful algal bloom, etc.) and did not provide data concerning other co-occurring stressors. Besides, the description of physical factors was usually scarce even for basic hydrological parameters like temperature, salinity, emersion time. Similarly, the presence of pathogens, pollutants, phycotoxins was analysed in terms of prevalence, levels or bioaccumulation but was rarely related to bivalve fitness. Conversely, studies dealing with fitness were rather (usually) in the framework of a population dynamics concern and did not take into account environmental stressors.

The second main difficulty was related to the heterogeneity of methods and units among studies, e.g. fresh flesh weight $v s$. dry flesh weight, whole body measurement $v s$. single organ measurement, parasite intensity (= number of parasites per infected individual) vs. parasite abundance (= number of parasites per individual), different spatial and temporal scales, etc. Finally, in order to compare the parameters that were measured in Arcachon Bay to international literature, we had to restrict our analysis to: 1) condition index for fitness evaluation; 2) Chla concentration in the water for environmental data; 3) perkinsosis (no comparison for Brown Muscle Disease which only exists in Arcachon Bay); 4) twelve trace elements; and 5) total hemocyte count (THC) as a response to stress (Table 1).

\section{Materials and methods}

\subsection{Study site}

Arcachon Bay is a $180-\mathrm{km}^{2}$ semi-sheltered lagoon on the southwest Atlantic coast of France (Fig. 1). It is subjected to continental water inputs through mainly the Leyre River but 
also many streams situated around the lagoon. In parallel, the lagoon receives marine waters from the Atlantic Ocean. Muddy intertidal flats colonized by Zostera noltei sea grass bed dominate the inner part of the lagoon $\left(110 \mathrm{~km}^{2}\right)$ whereas intertidal sand flats (Arguin, Fig. 1) are situated at the mouth of the bay. For this study, Arcachon Bay was divided in two sites: "Arcachon lagoon" (156 km²) and "Arguin" $\left(24 \mathrm{~km}^{2}\right)$ under oceanic influence. $R$. philippinarum is, in terms of biomass and excluding oyster culture, the dominant species of intertidal flats. The species inhabits both Arcachon lagoon and Arguin.

\subsection{R. philippinarum condition index}

Among the different possible condition indices, we selected the most consensual one for R. philippinarum :

$\mathrm{CI}=$ dry flesh weight (mg)/dry shell weight (g) (Walne and Mann, 1975).

Beyond $R$. philippinarum analyzed in the REPAMEP project in 2012 (Binias et al., 2014b), four other recent studies in Arcachon Bay (2003-12) were considered and compared as well as with ten others in the world based on the same CI calculations (Table 1).

\subsection{Chla in the water}

Chla concentration (in $\mu \mathrm{g} . \mathrm{L}^{-1}$ ) was the only environmental factor which average values could be found in a sufficient number of sites where $R$. philippinarum condition index was available. All data are from the literature (Table 1).

\subsection{Diseases}

In the framework of REPAMEP project, R. philippinarum was manually sampled at 39 sites in Arcachon Bay (Autumn 2009), at low tide (Binias et al., 2014a). Clams were found in 33 of these sites (Figure 1) and Perkinsus olseni abundance was estimated using the protocol 
from Ray (1952) modified by Choi et al. (1989). Clams were dissected and their gills were excised and weighed. The gills were incubated in $10 \mathrm{~mL}$ of fluid thioglycollate medium (FTM) supplemented with antifungal (Nystatin final concentration $40 \mathrm{mg} \mathrm{mL}{ }^{-1}$ ) and antibiotics (Streptomycin and penicillin $\mathrm{G}$ final concentration $66 \mathrm{mg} \cdot \mathrm{mL}^{-1}$ and $32 \mathrm{mg} \cdot \mathrm{mL}^{-1}$ respectively). Gills were incubated for at least one week in the dark at room temperature. After this time, the FTM was discarded following centrifugation $(10 \mathrm{~min}-800 \times \mathrm{g})$. Gill tissues were digested twice with $2 \mathrm{~N} \mathrm{NaOH}$ at $60{ }^{\circ} \mathrm{C}$ for $1 \mathrm{~h}$. After centrifugation (10 min-800 $\times \mathrm{g}$ ), the supernatant was discarded and the pellet washed twice with a sterile solution of Phosphate Buffered Saline and resuspended in $1 \mathrm{~mL}$ of the same solution. Perkinsus sp. hypnospores were enumerated on a Malassez counting chamber by light microscopy. The two parameters that could be compared with the literature were abundance and prevalence (Table 1). Abundance is defined as the number of cells per gram of wet gill tissues of analyzed clams and prevalence as the percentage of infected clams.

R. philippinarum from Arcachon Bay is also impacted by Brown Muscle Disease (BMD). Benefiting from a resource monitoring (Sanchez et al., 2013), a total of 497 stations were sampled (May-June 2012) to collect 11701 V. philippinarum all over the lagoon. Samples consisted in sediment cores $\left(0.25 \mathrm{~m}^{2}\right)$ using a Hamon grab, taken to a depth of $20 \mathrm{~cm}$. Individuals with shell length $\geq 23 \mathrm{~mm}$ (=threshold of infection according to previous studies) were dissected. The anterior muscle was observed under stereoscope to check necrosis related to BMD (Dang et al., 2008; Dang et al., 2009b). The prevalence was defined as the percentage of infected individuals ( $\geq 23 \mathrm{~mm})$.

\subsection{Trace element determination in clams and sediments}

During REPAMEP project, $R$. philippinarum was seasonally sampled at 6 sites (Arguin + 5 inner lagoon sites) in 2010, 2011 and 2012 (Fig. 1). Flesh of two individuals per replicate 
was extracted from the shell, mechanically homogenized and freezed under $-20^{\circ} \mathrm{C}$ until analysis. Twelve trace elements (silver 'Ag', aluminium 'Al', arsenic 'As', cadmium 'Cd', chromium 'Cr', cobalt 'Co', copper 'Cu', mercury 'Hg', manganese 'Mn', nickel 'Ni', lead ' $\mathrm{Pb}$ ' and zinc ' $\mathrm{Zn}$ ') were determined in 5 replicates per sampling site or time of total flesh $R$. philippinarum (in $\mu \mathrm{g} \cdot \mathrm{g}^{-1} \mathrm{dw}$ for dry weight) by ICP-OES (ICP-OES 720, Agilent Technologies) or ICP-MS (Thermo Fisher Scientific XSeries II). Aliquots of the biological samples were first digested in $3 \mathrm{~mL}$ of pure $\mathrm{HNO}_{3}$ (Merck, Darmstadt, Germany) in a pressurized medium at $100{ }^{\circ} \mathrm{C}$ for $3 \mathrm{~h}$ (hot block CAL 3300, Environmental Express, USA). Digestions were then diluted up to $18 \mathrm{~mL}$ with ultra-pure water (Milli-Q, Bedford, MA, USA). Three control samples (two CRMs and one blank) treated and analysed in the same way as the samples were included in each analytical batch. The CRMs were dogfish liver DOLT-4 (NRCC) and lobster hepatopancreas TORT-2 (NRCC). Trace element concentrations were expressed in $\mu \mathrm{g} \cdot \mathrm{g}^{-1} \mathrm{dw}$, which was the most consensual unit in the investigated literature (Table 2). The same sites were also sampled at one occasion for sediment analysis according to the same procedure. Only seven elements (As, $\mathrm{Co}, \mathrm{Cu}, \mathrm{Mn}$, $\mathrm{Ni}, \mathrm{Pb}$ and $\mathrm{Zn})$ were determined in these samples. The detection limits were $(\mu \mathrm{g} / \mathrm{L}): \mathrm{Ag} \mathrm{330}$; Al 310; As 200; Cd 214; Co 240; Cr 270; Cu 230; Mn 260; Ni 230; Pb 220; Zn 210.

Total $\mathrm{Hg}$ analyses were carried out by atomic absorption spectrophotometry with an Advanced Mercury Analyser (ALTEC AMA 254) on $0.1 \mathrm{~g}$ of dried clams. Mercury analyses were run under a thorough quality controlled program that includes analysis of certified reference material (CRM; lobster hepatopancreas TORT-2; National Research Council, Canada). Standard aliquots were treated and analysed according to the same conditions as the samples. The results were in good agreement with the certified values, with a mean recovery rate of $92 \%$. The detection limit of the method is $0.01 \mathrm{ng} \mathrm{Hg}$ with an average analytical variability of $5 \%$. 


\subsection{Total hemocyte count in $\mathrm{R}$. philippinarum}

Beyond R. philippinarum individuals that were analyzed in the REPAMEP project in 2012 (Binias et al., 2014b), we took into account results from a study performed in 2007 and 2008 (de Montaudouin et al., 2010) (Fig. 1, Table 1). The methodology was similar in both monitoring. Hemolymph was withdrawn from the posterior adductor muscle using a $1 \mathrm{~mL}$ syringe fitted with a 25 gauge needle. The hemolymph was filtered on $80 \mu \mathrm{m}$ mesh and stored on ice to minimize cell clumping. An aliquot of hemolymph $(100 \mu \mathrm{L})$ was diluted by adding $100 \mu \mathrm{L}$ of filtered sterile seawater and fixed with addition of $200 \mu \mathrm{L}$ of a formaldehyde solution at $6.4 \%$ in seawater. Total hemocyte count (THC) was measured by Flow Cytometry using a FACScalibur flow-cytometer (BD Biosciences, San Jose, CA) equipped with a 488 nm argon laser. Hemocyte cells were detected on the flow-cytometer using DNA marker $\left(\mathrm{SYBR}^{\circledR}\right.$ Green I) and their concentrations, in cells per $\mathrm{mL}$, were estimated from the flow rate measurement of the flow cytometer (Marie et al., 1999).

In order to compare the THC data obtained in the frame of the present work (cells maintained in formaldehyde solution at $4^{\circ} \mathrm{C}$, one week maximum before measurement) to the others works (THC done on live hemocytes), it is necessary to apply a correction to the obtained concentration. In fact, fixation induces some cell lost. The correction applied (C. Lambert Com. Pers.) is the following:

THC measured on live cells $=2648.42+1.33479$ x THC measured on fixed cells. (Pearson test, $\mathrm{P}=0.055, \mathrm{R}^{2}=0.75$ )

\subsection{Data treatment}

Results from Arcachon Bay were compared to 50 references from the literature on $R$. philippinarum in nine countries (France, Ireland, Italy, Portugal, Spain, USA, China, Korea, 
Japan; Table 1). Measured parameters were: condition index (CI), phytoplankton biomass through chlorophyll a concentrations (Chla, $\left.\mu \mathrm{g} . \mathrm{L}^{-1}\right)$, Perkinsus olseni abundance and prevalence (BMD was not compared due to its absence out of Arcachon Bay), trace element concentrations and total hemocyte count (THC). Only results on clams $>20 \mathrm{~mm}$, were taken into account for this study. This choice was motivated by the interest to work on mature individuals and to allow comparisons since this range was the most studied in the literature for cited parameters. Minimal and maximal mean values (e.g. minimal and maximal mean values in a monthly or seasonal monitoring) for each parameter measured in $R$. philippinarum from Arcachon lagoon were compared to individuals from Arguin, which is considered as an uncontaminated site out of Arcachon Bay (Fig. 1), and also compared to data from several other sites, according to international literature. Finally, Pearson correlation test was applied to compare condition index of $R$. philippinarum and Chla content in the water.

\section{Results}

\subsection{Condition index and relationship with Chlorophyll a concentration}

Condition index inside Arcachon lagoon was comprised between 32 and 46 (Fig. 2). This range is below those recorded at Arguin (out of the lagoon, in the oceanic part) (55 to 70) and those in other sites in the world (51 to 103).

When pooling all available data in the literature (Table 1), a significant positive correlation was observed between the median condition index and the median Chla concentrations in the water $(\mathrm{p}=0.008, \quad \mathrm{~N}=22$, Pearson Test; Fig. 3). Median Chla concentration variation explained $30 \%$ of CI variation. The correlation was not modified when taking into account whether $R$. philippinarum were in intertidal or subtidal position (not illustrated). 


\subsection{Perkinsus olseni prevalence and abundance}

Comparing available data (Table 1), the average maximum range of Perkinsus sp. abundance in $R$. philippinarum inside Arcachon lagoon was $2.09 \times 10^{5}$ cells g $^{-1}$ (in gill wet weight; Fig. 4). Perkinsosis is rare or absent from the outer part of the lagoon (Arguin), and other French northern sites such as Marennes-Oléron and Landéda (Lassalle et al., 2007). Morbihan station in France, as well as sites in Korea and Japan displayed higher maximal values $\left(>1.10^{6}\right.$ cells $\left.\mathrm{g}^{-1}\right)$.

P. olseni prevalence range was also high in Arcachon lagoon (70 to 100\%) (Fig 5). Similar levels are reached in Fangar Bay, Spain (57 to 100\%, Elandalloussi et al., 2008), Seonjaedo Island, Korea (38 to 97\%, Uddin et al., 2010) and Japan (57 to 94\%, Choi et al., 2002; Hamaguchi et al., 1998). In other French sites which are monitored for this parameter, prevalence is comprised between $0 \%$ in sites such as Arguin, Marennes-Oléron, Landéda, and $87 \%$ in Morbihan, France (Fig. 5).

\subsection{Brown Muscle Disease (BMD)}

Estimation of BMD prevalence in Arcachon lagoon during REPAMEP project was $4 \%$ of individuals with shell length $\geq 23 \mathrm{~mm}$, with high spatial heterogeneity. These results are not presented in the present paper because this disease was not described elsewhere.

\subsection{Trace element concentrations in clams and sediments}

R. philippinarum from Arcachon lagoon displayed maximal seasonal concentrations of nine trace elements 2 to 4 times higher than those from Arguin, namely $\mathrm{Al}(\times 2.5)$, As $(\times 2), \mathrm{Cd}$ (×3), $\mathrm{Co}(\times 2), \mathrm{Cr}(\times 2), \mathrm{Cu}(\times 2), \mathrm{Hg}(\times 4), \mathrm{Mn}(\times 3)$, and Ni (×2; Table 2). Conversely, Ag, Pb and $\mathrm{Zn}$ reached similar concentrations in the lagoon and at Arguin. 
In parallel, four elements reached higher maximal concentrations in Arcachon lagoon compared to other sites from the literature. Arsenic concentrations in the lagoon were 2-fold higher compared to Venice lagoon but are in the same order of magnitude as in Marano lagoon, Italy (Sfriso et al., 2008; Table 2). Concentrations of cobalt in Arcachon lagoon were also twice those previously recorded in Venice and Marano, Italy (Moschino et al., 2012; Sfriso et al., 2008) but was largely below concentrations in Korea (Ji et al., 2006). The highest nickel concentrations in Arcachon lagoon was two-fold the highest concentration recorded in other sites, i.e. in Kyeonggi Bay, Korea ( $\mathrm{Ji}$ et al., 2006). Finally, chromium maximal concentration in Arcachon lagoon was above all other studied sites, from 1.5 to 40 fold.

Concerning sediment contamination, all trace element concentrations (As, $\mathrm{Co}, \mathrm{Cu}, \mathrm{Mn}$, $\mathrm{Ni}, \mathrm{Pb}, \mathrm{Zn}$ ) were higher in Arcachon lagoon than in Arguin (Table 3). For example, Ni maximal mean concentration in the lagoon was approximately 18 -fold higher compared to those in Arguin. Concentrations of arsenic had also a tendency to be higher than in Italian sites. $\mathrm{Pb}$ and $\mathrm{Zn}$ maximal mean values were above other studied sites with the exception of the Venice lagoon (Table 3).

\subsection{Immune response: total hemocyte count (THC)}

THC in R. philippinarum from Arcachon lagoon is in the lower range of values recorded in the literature (Fig. 6). Indeed, THC reached maximal mean values of 800000 cell $\mathrm{mL}^{-1}$ while those of Brest and Marennes-Oléron reached 2400000 and 1750000 cell $\mathrm{mL}^{-1}$, respectively. The highest value was however observed in Southern Puget Sound, USA, with

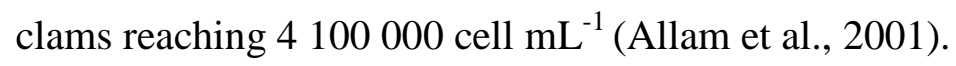

\section{Discussion}




\subsection{Condition index and relationship with Chlorophyll a concentration}

Condition index (CI) of bivalves gives a comprehensive idea of the fitness of the population (Beninger and Lucas, 1984; Marin et al., 2003). Ruditapes philippinarum CI values in Arcachon Bay are about half of what is observed in other parts of the world ([32-46] vs. [51-103], respectively, see references in Table 1) which suggests a particularly poor fitness. Other authors used morphological characteristics as a proxy for nutritional conditions (Caill-Milly et al., 2012 and 2014; Watanabe \& Katayama, 2010). Our results are consistent with such previous approach for which the globularity of the shell observed for Arcachon was in accordance with phenotypic changes under "unfavorable" conditions. This deficit of CI is not the only worrying parameter: recruitment and individual growth that were assessed in previous studies also highlight low values (Dang et al., 2010b; de Montaudouin et al., 2010). Two non-exclusive hypothesis can be evoked, genetic and/or phenotypic (Peterson and Beal, 1989). R. philippinarum was officially introduced at a single occasion in 1972 (Flassch and Leborgne, 1992) and a genetic impoverishment of the population could be expected. However, transplant experiments showed that Asari clams transported from the lagoon to the more oceanic area (Arguin) recovered in terms of CI (de Montaudouin, 2013) and growth (Dang et al., 2010b), even when they were parasitized by Perkinsus (Dang et al., 2010a). These results suggest a high phenotypic plasticity, i.e. that environment explains a significant part of R. philippinarum poor performances in the lagoon.

The only environmental parameter that could be statistically tested in relation with CI was the average concentration of Chla in the water. Primary production is associated with bivalve production including CI (Gam et al., 2010; Ivell, 1981; Möller and Rosenberg, 1983). Arcachon Bay is known as a mesotrophic lagoon with annual average Chla concentration of ca. $2 \mu \mathrm{g} . \mathrm{L}^{-1}$ (Glé, 2007). In this study, it is one of the lowest values recorded in waters where R. philippinarum is exploited and explains $30 \%$ of CI variability among investigated sites. 
This trophic deficit could be exacerbated by the intertidal position of $R$. philippinarum, emersion being a disadvantage for suspension-feeder growth (de Montaudouin, 1996; Peterson and Black, 1988). However, applying emersion time to our model (condition index as a function of Chla concentration in the water) did not change the results: the effect of emersion seems negligible compared to the effect of the low phytoplankton concentration in the water of Arcachon Bay. A recent study on morphological patterns related to environmental variability at the scale of four French sites also revealed significant relationships with chlorophyll $a$ concentrations even if the levels of Chla differed (Caill-Milly et al., 2014).

\subsection{Diseases}

Diseases represent another possibility to explain $R$. philippinarum health deficit and Arcachon lagoon appears at a hot spot with two dominant diseases, as already observed in 2007-08 (de Montaudouin et al., 2010). Whereas trematodiasis and brown ring disease (BRD) were not considered in this study due to their scarcity (Dang et al., 2009a; Lassalle et al., 2007), perkinsosis and brown muscle disease are at a high level of infection compared to other sites. Unfortunately, there are no available data correlating CI and Perkinsus concentration in $R$. philippinarum but there is evidence of a loss of fitness for these bivalves infected by P. olseni (Cigarría et al., 1997; Dang et al., 2013; Pretto et al., 2014; Shimokawa et al., 2010; Villalba et al., 2005; Waki et al., 2012; Yoshinaga et al., 2010). In Arcachon lagoon, the parasite abundance in gill can overpass $10^{5}$ cells.g fresh weight which is the suggested threshold to observe pathological effects (Dang et al., 2009a).

The other prevalent disease in R. philippinarum from Arcachon lagoon is the BMD. This disease was identified for the first time in Arcachon Bay in 2005 and consists in the progressive decay of posterior adductor muscle leading to death. Estimation of BMD 
prevalence in Arcachon lagoon during REPAMEP project was 4\% of individuals with shell length $\geq 23 \mathrm{~mm}$. There is no possible comparison with other sites. Indeed, so far, this disease was observed only in Arcachon lagoon, although there was a suspicion in Portugal (Pers observation) and in Great Britain (Bateman et al., 2012). Nevertheless, BMD participates to the global fitness deficit of $R$. philippinarum (Binias et al., 2014b; Dang and de Montaudouin, 2009) compared to other sites which are all BMD-free.

\subsection{Trace elements}

Trace element concentrations, in average, display relatively low values although some (9 among the investigated elements) are over values observed in other ecosystems exploiting $R$. philippinarum. Data on aluminum remain scarce and none concerns $R$. philippinarum. So far, effect of $\mathrm{Al}$ on $R$. philippinarum health is unknown. On one hand, arsenic maximum average concentration in $R$. philippinarum in inner Arcachon Bay is twice higher than in clams from Arguin and are similar to concentrations observed in the industrialized inner lagoon of Venice in Italy (Moschino et al., 2012). Arcachon Bay is not an industrialized area but however sediment As concentrations were also relatively high and over ERL (Effect Range-Low) threshold as defined by Long et al. (1995). On the other hand, Arcachon As concentrations in R. philippinarum remain below national median in Mytilus edulis (I.F.R.E.MER, 2005). The deleterious effect of As for organisms remains delicate to claim because its toxicity depends on its chemical form. Despite a high cadmium bioaccumulation potential in $R$. philippinarum (Baudrimont et al., 2005), maximal cadmium concentrations remained low in the present study with a maximal value of $0.66 \mu \mathrm{g} \cdot \mathrm{g}^{-1} \mathrm{dw}$ (below consumption safety level, CE No. 466/2001). This is slightly over Arguin value $\left(\max =0.23 \mu \mathrm{g} \cdot \mathrm{g}^{-1} \mathrm{dw}\right.$ ) and similar to concentrations of $R$. philippinarum challenged with fairly pristine sediment of Bay of Cadiz (Spain) (Riba López et al., 2010), or of R. philippinarum in the most oceanic and unpolluted 
part of Venice lagoon in Italy (Moschino et al., 2012). The highest recorded values coincide with concentrations for which some cellular responses (as metallothionein synthesis) of clams were detected with putative minor stress (de Montaudouin et al., 2010). However, values are much lower than in areas where pollution is obvious as in Jiaozhou Bay in China (Wang et al., 2010) or inner Venice lagoon (Moschino et al., 2012). Chromium concentrations in $R$. philippinarum in Arcachon Bay, both at Arguin and Arcachon lagoon, are in the same ranges of the sites known to be polluted such as Jiaozhou Bay, China (Wang et al., 2010) and 7-11 times higher than in other contaminated sites of Cadiz Bay (Spain) (Riba López et al., 2010) or Venice lagoon (Moschino et al., 2012). Manganese is a required trace element for all living organisms (enzyme cofactor) that however is rarely measured in $R$. philippinarum. In Arcachon Bay, it is in the range of levels measured in Italy but about two fold lower than in Asian sites, Jiaozhou Bay (China) (Wang et al., 2010), and Kyeonggi Bay (Korea) (Ji et al., 2006). Like chromium, nickel is at a high level in Arcachon lagoon, with maximal concentrations in $R$. philippinarum almost as high as those observed in polluted area of Jiaozhou Bay (China) (Wang et al., 2010). Conversely, concentrations in sediment are rather low compared to this Chinese bay and other sites reviewed in the related study (Wang et al., 2010), and are below ERL guideline (Long et al., 1995). Most mercury compounds are toxic and dangerous at very low levels in both aquatic and terrestrial ecosystems. Mercury is a persistent substance and bioaccumulates in living organisms like suspension-feeding bivalves. The maximal concentrations range around $1.2 \mathrm{~g} \cdot \mathrm{g}^{-1} \mathrm{dw}$, which is a higher value than the maximal concentrations recorded in Cadiz Bay (Spain) (Riba López et al., 2010), in North Médoc (France) (Baudrimont et al., 2005) or Venice lagoon (Italy) (Moschino et al., 2012) and slightly higher than the French National median for Mytilus edulis $\left(1.1 \mu \mathrm{g} \cdot \mathrm{g}^{-1} \mathrm{dw}\right)$.

\subsection{Total hemocyte count (THC)}


To assess apparent resistance of $R$. philippinarum in their environment many molecular and cellular biomarkers are available. However, the only one that could be compared among a relevant number of sites or studies was the THC. THC is often, but not always, correlated to other parameters involved in the immune response that would contribute to clam defenses against pathogens, e.g. hemocyte viability, phagocytic activity, adhesion etc. (Allam and Ford, 2006; Paul-Pont et al., 2010b). Thus, low THC values in $R$. philippinarum from Arcachon lagoon compared to those from other sites suggest a certain weakness to react to stress. In particular, our data show that clams from Arcachon lagoon display "low maxima" 2 to 6 fold lower as compared to other sites, reinforcing the idea that they would have low capacity to react against stressors including pathogens.

\section{Conclusion}

Difficulty to obtain really comparable data must be reminded to explain the heterogeneity of results. However, there is strong evidence that Asari clams from Arcachon lagoon display low condition index compared to all other sites and that a significant cause is the low values of Chla in plankton. Moreover, condition index and Chla concentrations are also relatively low at Arguin where disease and element contamination are at very low levels. Low Chla concentration values in the water column and poor $R$. philippinarum condition index may also rise the hypothesis that the carrying capacity for filter feeders in Arcachon Bay is reached. High biomass of bivalves (mostly oysters Crassostrea gigas) has been recorded in Arcachon Bay (Sanchez et al., 2013; Scourzic et al., 2011) which could deplete seston and exert a topdown control of primary production. Carrying capacity evaluation necessities robust dynamic models and remains difficult to obtain (McKindsey et al., 2006). It was successfully performed in few coastal areas in relation with aquaculture (Bacher et al., 1998; Dame and Prins, 1998) and should be a research perspective in Arcachon Bay. After trophic source 
deficit, perkinsosis appears as a particularly prevalent disease, with high parasite abundance. Brown Muscle Disease is only present in Arcachon bay and represents undoubtedly a supplementary handicap for its Asari clam population. Trace element concentrations in clams are, in average, at lower levels than levels tolerated regarding regulatory issues but often at higher concentration than in other sites with $R$. philippinarum production. Beyond average, it would be relevant to look for element concentration peaks and especially regarding nickel and chromium. Finally, this study suffers from limitations in terms of stressors that were measured in this REPAMEP project and/or that were investigated in other sites for comparison (PAH, harmful algal blooms, pesticides ...), considering that it is now admitted that these stressors can interact on bivalve response with additive, synergistic or antagonistic effects (Lassudrie et al., 2014; Paul-Pont et al., 2010a,b). Besides, antimicrobial peptides in oyster hemolymph proved to have a bacterial origin suggesting to take into account the role of hosted bacteriocinogenic bacteria into bivalve defense (Defer et al. 2013). Changes in the hosted microbiota can occur under environmental stress which, in the particular instance of bacteriocinogenic bacteria, could affect the bivalve defense and finally the bivalve fitness, consistently with the hologenome theory (Zilber-Rosenberg and Rosenberg, 2008). The assessment of bacterial community in clam individuals from different origins would allow addressing this question for the Asari clam microbiota.

\section{ACKNOWLEDGEMENTS}

This study was partly financed by French Ministry for Environment, LITEAU Programme, REPAMEP Project L.11-6778. Field sampling necessitated Planula boat and crew (INSU). Part of the data were collected in the context of the Asari clam monitoring financed by 
Europe, French government, Aquitaine Regional Council, Gironde General Council and fishing professional organization.

\section{REFERENCES}

Allam, B., Ashton-Alcox, K.A., Ford, S.E., 2001. Haemocyte parameters associated with resistance to brown ring disease in Ruditapes spp. clams. Dev. Comp. Immunol. 25, 365375.

Allam, B., Ford, S.E., 2006. Effects of the pathogenic Vibrio tapetis on defence factors of susceptible and non-susceptible bivalve species: I. Haemocyte changes following in vitro challenge. Fish Shellfish Immunol. 20, 374-383.

Allam, B., Paillard, C., Auffret, M., 2000. Alterations in hemolymph and extrapallial fluid parameters in the Manila Clam, Ruditapes philippinarum, challenged with the pathogen Vibrio tapetis. J. Invertebrate Pathol. 76, 63-69.

Bacher, C., Duarte, P., Ferreira, J.G., Héral, M., Raillard, O., 1998. Assessment and comparison of the Marennes-Oléron Bay (France) and Carlingford Lough (Ireland) carrying capacity with ecosystem models. Aquat. Ecol. 31, 379-394.

Bacher, C., Goulletquer, P., 1989. Comparaison des relations trophiques de Ruditapes philippinarum en milieu estuarien et océanique à partir d'un modèle de croissance. Can. J. Fish. Aquat. Sci. 46, 1160-1170.

Baek, M.J., Lee, Y.-J., Choi, K.-S., Lee, W.C., Park, H.J., Kwak, J.H., Kang, C.-K., 2014. Physiological disturbance of the Manila clam, Ruditapes philippinarum, by altered environmental conditions in a tidal flat on the west coast of Korea. Mar. Poll. Bull. 78, 137-145. 
Bateman, K.S., White, P., Longshaw, M., 2012. Virus-like particles associated with mortalities of the Manila clam Ruditapes philippinarum in England. Dis. Aquat. Org. 99, 163-167.

Baudrimont, M., Schäfer, J., Marie, V., Maury-Brachet, R., Bossy, C., Boudou, A., Blanc, G., 2005. Geochemical survey and metal bioaccumulation of three bivalve species (Crassostrea gigas, Cerastoderma edule, and Ruditapes philippinarum) in the Nord Médoc salt marshes (Gironde estuary, France). Sci. Tot. Envir. 337, 265-280.

Beninger, P.G., Lucas, A., 1984. Seasonal variations in condition, reproductive activity, and gross biochemical composition of two species of adult clam reared in a common habitat: Tapes decussatus L. (Jeffreys) and Tapes philippinarum (Adams \& Reeve). J. Exp. Mar. Biol. Ecol. 79, 19-37.

Binias, C., Do, V.T., Jude-Lemeilleur, F., Plus, M., Froidefond, J.M., de Montaudouin, X., 2014a. Environmental factors contributing to the development of Brown Muscle Disease and perkinsosis in Manila clams (Ruditapes philippinarum) and trematodiasis in cockles (Cerastoderma edule) of Arcachon Bay. Mar. Ecol. 35, 67-77.

Binias, C., Gonzalez, P., Provost, M., Lambert, C., de Montaudouin, X., 2014b. Brown muscle disease: impact on Manila clam Venerupis (=Ruditapes) philippinarum biology. Fish Shellfish Immunol. 36, 510-518.

Boscolo, R., Cornello, M., Giovanardi, O., 2003. Condition index and air survival time to compare three kinds of Manila clams Tapes philippinarum (Adams \& Reeve) farming systems. Aquacult. Int. 11, 243-254.

Brock, V., 1980. Notes on relations between density, settling, and growth of two sympatric cockles, Cardium edule (L.) and C. glaucum (Bruguière). Ophelia Suppl. 1, 241-248.

Bruchon, F., Nogues, L., Riou, P., LeGoff, R., Nedelec, F., 2008. Combining monitoring networks, hydrodynamic modelling and satellite data to a better understanding of the 
trophic functioning of coastal waters in Normandy, in: Ceccaldi, H.-J., Dekeyser, I., Girault, M., Stora, G. (Eds.), 13th French-Japanese oceanography symposium. Global change: mankind-marine environment interactions. Springer, Marseille, France, pp. 325334.

Byrne, P.A., O'Halloran, J., 2001. The role of bivalve molluscs as tools in estuarine sediment toxicity testing: a review. Hydrobiologia 465, 209-217.

Caill-Milly, N., Bru, N., Barranger, M., Gallon, L., D’Amico, F., 2014. Morphological trends of four Manila clam populations (Venerupis philippinarum) on the French atlantic coast: identified spatial patterns and their relationship to environmental variability. J. Shellfish Res. 33 (2), 355-372.

Caill-Milly, N., Bru, N., Mahe, K., Borie, C., D'Amico, F., 2012. Shell shape analysis and spatial allometry patterns of Manila clam (Ruditapes philippinarum) in a mesotidal coastal lagoon. J. Mar. Biol. ID 281206, 1-11.

Carnegie, R.B., 2005. Effects in mollusc culture, in: Rohde, K. (Ed.), Marine parasitology. CSIRO \& CABI, Collingwood, Australia, pp. 391-398.

Carroll, M.L., Johnson, B.J., Henkes, G.A., McMahon, K.W., Voronkov, A., Ambrose, W.G., Denisenko, S.G., 2009. Bivalves as indicators of environmental variation and potential anthropogenic impacts in the southern Barents Sea. Mar. Poll. Bull. 59, 193-206.

Choi, H.-S., Park, K.-I., Lee, K.-W., Matsuoka, K., 2002. Infection intensity, prevalence, and histopathology of Perkinsus sp. in the Manila clam, Ruditapes philippinarum, in Isahaya bay, Japan. J. Shellfish Res. 21, 119-125.

Choi, H.-S., Wilson, E.A., Lewis, D.H., Powell, E.N., Ray, S.M., 1989. The energic cost of Perkinsus marinus parasitism in oyster: quantification of the thioglycollate method. J. Sea Res. 8, 125-131. 
Cigarría, J., Rodrígues, J.M., Fernández, J.M., 1997. Impact of Perkinsus sp. on Manila clam Ruditapes philippinarum beds. Dis. Aquat. Org. 29, 117-120.

da Silva, P.M., Hégaret, H., Lambert, C., Wikfors, G.H., Le Goïc, N., Shumway, S.E., Soudant, P., 2008. Immunological responses of the Manila clam (Ruditapes philippinarum) with varying parasite (Perkinsus olseni) burden, during a long-term exposure to the harmful alga, Karenia selliformis, and possible interactions. Toxicon 51, 563-573.

Dame, R.F., Prins, T.C., 1998. Bivalve carrying capacity in coastal ecosystems. Aquat. Ecol. $31,409-421$.

Dang, C., de Montaudouin, X., 2009. Brown Muscle Disease and Manila clam Ruditapes philippinarum dynamics in Arcachon Bay, France. J. Shellfish Res. 28, 355-362.

Dang, C., de Montaudouin, X., Bald, J., Jude, F., Raymond, N., Lanceleur, L., Paul-Pont, I., Caill-Milly, N., 2009a. Testing the Enemy Release Hypothesis: Trematode parasites in the non indigenous Manila clam Ruditapes philippinarum. Hydrobiologia 630, 139-148.

Dang, C., de Montaudouin, X., Binias, C., Salvo, F., Caill-Milly, N., Bald, J., Soudant, P., 2013. Correlation between perkinsosis and growth in clams Ruditapes spp. Dis. Aquat. Org. 106, 255-265.

Dang, C., de Montaudouin, X., Caill-Milly, N., Trumbic, Ž., 2010a. Spatio-temporal patterns of perkinsosis in the Manila clam Ruditapes philippinarum from Arcachon Bay (SW France). Dis. Aquat. Org. 91, 151-159.

Dang, C., de Montaudouin, X., Gam, M., Paroissin, C., Caill-Milly, N., 2010b. The Manila clam population in Arcachon Bay (SW France): can it be kept sustainable? J. Sea Res. 63, 108-118. 
Dang, C., de Montaudouin, X., Gonzalez, P., Mesmer-Dudons, N., Caill-Milly, N., 2008. Brown Muscle Disease (BMD), an emergent pathology affecting Manila clam Ruditapes philippinarum in Arcachon bay (SW France). Dis. Aquat. Org. 80, 219-228.

Dang, C., Gonzalez, P., Mesmer-Dudons, N., Bonami, J.R., Caill-Milly, N., de Montaudouin, X., 2009b. Virus-like particles associated with Brown Muscle Disease in Manila clam (Ruditapes philippinarum) in Arcachon Bay (France). J. Fish Dis. 32, 577-584.

Daou, R., Goulletquer, P., 1988. Effets de la turbidité sur les palourdes adultes Ruditapes philippinarum (Adams \& Reeve): croissance, mortalité, effort de reproduction, composition biochimique. Océanis 14, 375-389.

Darecki, M., Weeks, A., Sagan, S., Kowalczuk, P., Kaczmarek, S., 2003. Optical characteristics of two contrasting Case 2 waters and their influence on remote sensing algorithms. Cont. Shelf Res. 23, 237-250.

de Montaudouin, X., 1996. Factors involved in growth plasticity of cockles Cerastoderma edule (L.) identified by field survey and transplant experiments. J. Sea Res. 36, 251-265.

de Montaudouin, X., 2013. Projet Liteau 3 : Réponse des palourdes aux stress environnementaux combinant métaux, efflorescences toxiques et pathogènes - Rapport final. Université Bordeaux 1 - CNRS, UMR EPOC 5805, Arcachon, p. 105.

de Montaudouin, X., Bachelet, G., 1996. Experimental evidence of complex interactions between biotic and abiotic factors in the dynamics of an intertidal population of the bivalve Cerastoderma edule. Oceanol. Acta 19, 449-463.

de Montaudouin, X., Kisielewski, I., Bachelet, G., Desclaux, C., 2000. A census of macroparasites in an intertidal bivalve community, Arcachon Bay, France. Oceanol. Acta $23,453-468$.

de Montaudouin, X., Paul-Pont, I., Lambert, C., Gonzalez, P., Raymond, N., Jude, F., Legeay, A., Baudrimont, M., Dang, C., Le Grand, F., Le Goïc, N., Bourasseau, L., Paillard, C., 
2010. Bivalve population health: multistress to identify hot spots. Mar. Poll. Bull. 60, $1307-1318$

Defer, D., Desriac F., Henry J. Bourgougnon, N.,Baudy-Floc'h M., Brillet B., Le Chevalier P., Fleury Y. (2013). Antimicrobial peptides in oyster hemolymph: The bacterial connection. Fish Shellfish Immunol. 34(6): 1439-1447.

Delaporte, M., Soudant, P., Moal, J., Lambert, C., Quéré, C., Miner, P., Choquet, G., Paillard, C., Samain, J.-F., 2003. Effect of a mono-specific algal diet on immune functions in two bivalve species - Crassostrea gigas and Ruditapes philippinarum. J. Exp. Biol. 206, 3053-3064.

Drummond, L., Mulcahy, M., Culloty, S., 2006. The reproductive biology of the Manila clam, Ruditapes philippinarum, from the North-West of Ireland. Aquaculture 254, 326-340.

Dutertre, M., Hamon, D., Chevalier, C., Ehrhold, A., 2013. The use of the relationships between environmental factors and benthic macrofaunal distribution in the establishment of a baseline for coastal management. ICES J. Mar. Sci. 70, 294-308.

Elandalloussi, L.M., Carrasco, N., Roque, A., Fernández-Tejedor, M., Furones, D., 2008. Occurence of Perkinsus sp. in two clam species (Ruditapes philippinarum and $R$. decussatus from the Ebro delta, Spain. Bull. Eur. Ass. Fish Pathol. 28, 1-9.

Fan, D., Zhang, A., Yang, Z., Sun, X., 2007. Observations on shell growth and morphology of bivalve Ruditapes philippinarum. Chin. J. Oceanol. Limnol. 25(3), 322-329.

FAO, 2014. www.fao.org/fishery/statistics/en

Flassch, J.-P., Leborgne, Y., 1992. Introduction in Europe, from 1972 to 1980, of the Japanese Manila clam (Tapes philippinarum) and the effects on aquaculture production and natural settlement. ICES mar. Sci. Symp. 194, 92-96. 
Flye-Sainte-Marie, J., Soudant, P., Lambert, C., Le Goïc, N., Goncalvez, M., Travers, M.-A., Paillard, C., Jean, F., 2009. Variability of the hemocyte parameters of Ruditapes philippinarum in the field during an annual cycle. J. Exp. Mar. Biol. Ecol. 377, 1-11.

Fukumori, K., Oi, M., Doi, H., Okuda, N., Yamaguchi, H., Kuwae, M., Miyasaka, H., Yoshino, K., Koizumi, Y., Omori, K., Takeoka, H., 2008. Food sources of the pearl oyster in coastal ecosystems of Japan: evidence from diet and stable isotope analysis. Estuar. Coast. Shelf Sci. 76, 704-709.

Gam, M., Bazaïri, H., Jensen, K.T., de Montaudouin, X., 2008. Metazoan parasites in an intermediate host population near its southern border: the common cockle (Cerastoderma edule) and its trematodes in a Moroccan coastal lagoon (Merja Zerga). J. Mar. Biol. Ass. U.K. $88,357-364$.

Gam, M., de Montaudouin, X., Bazaïri, H., 2010. Population dynamics and secondary production of the cockle Cerastoderma edule: comparison between Merja Zerga (Moroccan Atlalntic Coast) and Arcachon (French Atlantic coast). J. Sea Res. 63, 191201.

Glé, C., 2007. Structure et dynamique des communautés microbiennes autotrophes et production primaire planctonique dans une lagune côtière macrotidale, le Bassin d'Arcachon. Facteurs de contrôle de type bottom-up. University Bordeaux 1, p. 309.

Goulletquer, P., 1989. Mortalité hivernale chez la palourde japonaise Ruditapes philippinarum sur le littoral atlantique: aspects biochimique et écophysiologique. Haliotis $19,215-226$.

Guerlet, E., Vasseur, P., Giambérini, L., 2010. Spatial and temporal variations of biological responses to environmental pollution in the freshwater zebra mussel. Ecotoxicol. Environ. Saf. 73, 1170-1181. 
Gunatilaka, A., Moscetta, P., Sanfilippo, L., Savino, E., Dell'Olivo, C., Scardia, F., Gurato, A., Cisneros-Aguirre, J., 2009. Observations on continuous nutrient monitoring in Venice Lagoon, in: MTS/IEEE (Ed.), OCEANS 2009. Marine technology for our future: global and local challenges. IEEE, Biloxi, Mississippi, USA, pp. 1-7.

Hamaguchi, M., Suzuki, N., Usuki, H., Ishioka, H., 1998. Perkinsus protozoan infection in short-necked clam Tapes (=Ruditapes) philippinarum in Japan. Fish Pathol. 33, 473-480.

Hégaret, H., da Silva, P.M., Wikfors, G.H., Lambert, C., De Bettignies, T., Shumway, S.E., Soudant, P., 2007. Hemocyte response of Manila clams, Ruditapes philippinarum, with varying parasite, Perkinsus olseni, severity to toxic-algal exposures. Aquat. Toxicol. 84, 469-479.

I.F.R.E.MER, 2005. Bilan 2004 du réseau REPAMO. Ifremer, p. 69.

I.F.R.E.MER, 2011. Bulletin de la surveillance de la qualité du milieu marin littoral 2010. Morbihan. Ifremer, pp. 1-115.

I.F.R.E.MER, 2013. Bulletin de la surveillance de la qualité du milieu marin littoral 2012. Finistère. Ifremer, pp. 1-149.

Ivell, R., 1981. A quantitative study of a Cerastoderma - Nephthys community in the Limfjord, Denmark, with special reference to production of Cerastoderma edule. J. Moll. Stud. 47, 147-170.

Ji, J., Choi, H.J., Ahn, I.-Y., 2006. Evaluation of Manila clam Ruditapes philippinarum as a sentinel species for metal pollution monitoring in estuarine tidal flats of Korea: effects of size, sex, and spawning on baseline accumulation. Mar. Poll. Bull. 52, 447-468.

Jonsson, P.R., André, C., 1992. Mass mortality of the bivalve Cerastoderma edule on the Swedish west coast caused by infestation with the digenean trematode Cercaria cerastodermae I. Ophelia 36, 151-157. 
Kamermans, P., Veer, H.W.V.d., Karczmarski, L., Doeglas, G.W., 1992. Competition in deposit- and suspension-feeding bivalves: experiments in controlled outdoor environments. J. Exp. Mar. Biol. Ecol. 162, 113-135.

Kim, Y., Powell, E.N., Wade, T.L., Presley, B.J., 2008. Relationship of parasites and pathologies to contaminant body burden in sentinel bivalves: NOAA status and trends "mussel watch" program. Mar. Env. Res. 65, 101-127.

Lassalle, G., de Montaudouin, X., Soudant, P., Paillard, C., 2007. Parasite co-infection of two sympatric bivalves, the Manila clam (Ruditapes philippinarum)/and the cockle (Cerastoderma edule) along a latitudinal gradient. Aquat. Living. Resour. 20, 33-42.

Lassudrie, M., Soudant, P., Richard, G., Henry, N., Mehdiouf, W., da Silva, P.M., Donval, A., Bunel, M., Le Goïc, N., Lambert, C., de Montaudouin, X., Fabioux, C., Hégaret, H., 2014. Physiological responses of Manila clams Venerupis (=Ruditapes philippinarum) with varying parasite Perkinsus olseni burden to toxic algal Alexandium ostenfeldii exposure. Aquat. Toxicol. In press.

Lehtonen, K.K., Leiniö, S., Schneider, R., Leivuori, M., 2006. Biomarkers of pollution effects in the bivalves Mytilus edulis and Macoma balthica collected from the southern coast of Finland (Baltic Sea). Mar. Ecol. Prog. Ser. 322, 155-168.

Long, E.R., Macdonald, D.D., Smith, S.L., Calder, F.D., 1995. Incidence of adverse biological effects within ranges of chemical concentrations in marine and estuarine sediments. Environ. Manage. 19, 81-97.

Lopez, C.B., Pereira, M.E., Vale, C., Lillebø, A.I., Pardal, M.Â, Duarte, A.C., 2007. Assessment of spatial environmental quality status in Ria de Aveiro (Portugal). Scientia Marina 71, 293-304.

Marie, D., Partensky, F., Vaulot, D., Brussaard, C.P.D., 1999. Enumeration of phytoplankton, bacteria, and viruses in marine samples, in: Robinson, J.P., Darzynkiewicz, Z., Dean, 
P.N., Orfao, A., Rabinovitch, P., Stewart, C., Tanke, H.J., Wheeless, L. (Eds.), Current protocols in cytometry. John Wiley \& Sons, Inc., New York, pp. 11-15.

Marin, M.G., Moschino, V., Deppieri, M., Lucchetta, L., 2003. Variations in gross biochemical composition, energy value and condition index of T. philippinarum from the Lagoon of Venice. Aquaculture 219, 859-871.

McKindsey, C.W., Thetmeyer, H., Landry, T., Silvert, W., 2006. Review of recent carrying capacity models for bivalve culture and recommendation for research and management. Aquaculture 261, 451-462.

Mearns, A.J., Reish, D.J., Oshida, P.S., Ginn, T., Rempel-Hester, M.A., Courtney, A., 2012. Effects of pollution on marine organisms. Water Env. Res. 84, 1737-1823.

Möller, P., Rosenberg, R., 1983. Recruitment, abundance and production of Mya arenaria and Cardium edule in marine shallow waters, Western Sweden. Ophelia 22, 33-55.

Morley, N.J., 2010. Interactive effects of infectious diseases and pollution in aquatic molluscs. Aquat. Toxicol. 96, 27-36.

Moschino, V., Delaney, E., Da Ros, L., 2012. Assessing the significance of Ruditapes philippinarum as a sentinel for sediment pollution: bioaccumulation and biomarker responses. Env. Poll. 171, 52-60.

Nam Han, K., Woo Lee, S., Youn Wang, S., 2008. The effect of temperature on the energy budget of the Manila clam, Ruditapes philippinarum. Aquacult. Int. 16, 143-152.

Navas, J.I., Castillo, M.C., Vera, P., Ruiz-Rico, M., 1992. Principal parasites observed in clams, Ruditapes decussatus (L.), Ruditapes philippinarum (Adams et Reeve), Venerupis pullastra (Montagu) and Venerupis aureus (Gmelin), from the Huelva coast (S.W. Spain). Aquaculture 107, 193-199.

Newell, R.I.E., 2004. Ecosystem influences of natural and cultivated populations of suspension-feeding bivalve molluscs: a review. J. Shellfish Res. 23, 51-61. 
Ngo, T.T.T., Choi, K.-S., 2004. Seasonal changes of Perkinsus and Cercaria infections in the Manila clam Ruditapes philippinarum from Jeju, Korea. Aquaculture 239, 57-68.

Pan, K., Wang, W.-X., 2011. Mercury accumulation in marine bivalves: influences of biodynamics and feeding niche. Env. Poll. 159, 2500-2506.

Park, K.-I., Choi, K.-S., 2001. Spatial distribution of the protozoan parasite Perkinsus sp. found in the Manila clams, Ruditapes philippinarum, in Korea. Aquaculture 203, 9-22.

Park, K.-I., Figueras, A., Choi, K.-S., 2006. Application of enzyme-linked immunosorbent assay (ELISA) for the study of reproduction in the Manila clam Ruditapes philippinarum (Mollusca: Bivalvia):II. Impacts of Perkinsus olseni on clam reproduction. Aquaculture $251,182-191$.

Paul-Pont, I., Baudrimont, M., Gonzalez, P., de Montaudouin, X., 2010a. Interactive effects of metal contamination and pathogenic organisms on the marine bivalve Cerastoderma edule. Mar. Poll. Bull. 60, 515-525.

Paul-Pont, I., de Montaudouin, X., Gonzalez, P., Jude, F., Raymond, N., Paillard, C., Baudrimont, M., 2010b. Interactive effects of metal contamination and pathogenic organisms on the introduced marine bivalve Ruditapes philippinarum in European populations. Env. Poll. 158, 3401-3410.

Peterson, C.H., 1982. The importance of predation and intra- and interspecific competition in the population biology of two infaunal suspension-feeding bivalves, Protothaca staminea and Chione undatella. Ecol. Monogr. 52, 437-475.

Peterson, C.H., Beal, B.F., 1989. Bivalve growth and higher order interactions: importance of density, site, and time. Ecology 70, 1390-1404.

Peterson, C.H., Black, R., 1987. Resource depletion by active suspension feeders on tidal flats: influence of local density and tidal elevation. Limnol. Oceanogr. 32, 143-166. 
Peterson, C.H., Black, R., 1988. Responses of growth to elevation fail to explain vertical zonation of suspension-feeding bivalves on a tidal flat. Oecologia 76, 423-429.

Pretto, T., Zambon, M., Civettini, M., Caburlotto, G., Boffo, L., Rossetti, E., Arcangeli, G., 2014. Massive mortality in Manila clams (Ruditapes philippinarum) farmed in the Lagoon of Venice, caused by Perkinsus olseni. Bull. Eur. Ass. Fish Pathol. 34, 43-53.

Ramón, M., 1996. Relationships between the bivalves Mytilus edulis L. and Cerastoderma edule (L.) in a soft bottom environment: an example of interaction at small spatial scale. J. Exp. Mar. Biol. Ecol. 204, 179-194.

Riba López, I., Kalman, J., Vale, C., Blasco, J., 2010. Influence of sediment acidification on the bioaccumulation of metals in Ruditapes philippinarum. Env. Sci. Pollut. Res. 17, $1519-1528$

Rowley, A.F., Cross, M.E., Culloty, S.C., Lynch, S.A., Mackenzie, C.L., Morgan, E., O'Riordan, R.M., Robins, P.E., Smith, A.L., Thrupp, T.J., Vogan, C.L., Wootton, E.C., Malham, S.K., 2014. The potential impact of climate change on the infectious diseases of commercially important shellfish populations in the Irish Sea - a review. ICES J. Mar. Sci. 71, 741-759.

Sanchez, F., Caill-Milly, N., de Casamajor, M.-N., Lissardy, M., Binias, C., Bru, N., 2013. Campagne d'évaluation du stock de palourdes du bassin d'Arcachon. Ifremer, p. 38.

Sanchez, F., Caill-Milly, N., Lissardy, M., Bru, N., 2014. Campagne d'évaluation du stock de palourdes du bassin d'Arcachon. Ifremer, p. 53.

Sarà, G., Mazzola, A., 2004. The carrying capacity for Mediterranean bivalve suspension feeders: evidence from analysis of food availability and hydrodynamics and their integration into a local model. Ecol. Model. 179, 281-296. 
Scourzic, T., Loyen, M., Fabre, E., Tessier, A., Dalias, N., Trut, G., Maurer, D., Simonnet, B., 2011. Evaluation du stock d'huîtres sauvages et en élevage dans le Bassin d'Arcachon. Agence des Aires Marines Protégées \& OCEANIDE, p. 70.

Sfriso, A., Argese, E., Bettiol, C., Facca, C., 2008. Tapes philippinarum seed exposure to metals in polluted areas of the Venice lagoon. Estuar. Coast. Shelf Sci. 79, 581-590.

Sfriso, A., Facca, C., Ghetti, P.F., 2003. Temporal and spatial changes of macroalgae and phytoplankton in a Mediterranean coastal area: the Venice lagoon as a case study. Mar. Env. Res. 56, 617-636.

Shimokawa, J., Yoshinaga, T., Ogawa, K., 2010. Experimental evaluation of the pathogenicity of Perkinsus olseni in juvenile Manila clams Ruditapes philippinarum. J. Invertebrate Pathol. 105, 347-351.

SOMLIT, 2014. www.somlit.epoc.u-bordeaux1.fr/fr/

Soudant, P., Paillard, C., Choquet, G., Lambert, C., Reid, H.I., Marhic, A., Donaghy, L., Birkbeck, T.H., 2004. Impact of season and rearing site on the physiological and immunological parameters of the Manila clam Venerupis (=Tapes, =Ruditapes) philippinarum. Aquaculture, 401-418.

Suh, Y.J., Shin, K.-H., 2013. Size-related and seasonal diet of the manila clam (Ruditapes philippinarum), as determined using stable isotopes. Estuar. Coast. Shelf Sci. 135, 94105.

Thieltges, D.W., 2006. Parasite induced summer mortality in the cockle Cerastoderma edule by the trematode Gymnophallus choledochus. Hydrobiologia 559, 455-461.

Thieltges, D.W., Reise, K., 2007. Spatial heterogeneity in parasite infections at different spatial scales in an intertidal bivalve. Oecologia 150, 569-581. 
Trombini, C., Fabbri, D., Lombardo, M., Basura, I., Zavoli. E., Horvat, M., 2003. Mercury and methylmercury contamination in surficial sediments and clams of a coastal lagoon (Pialassa Baiona, Ravenna, Italy). Cont. Shelf Res. 23, 1821-1831.

Troost, K., Stamhuis, E.J., van Duren, L.A., Wolff, W.J., 2009. Feeding current characteristics of three morphologically different suspension feeders, Crassostrea gigas, Mytilus edulis and Cerastoderma edule, in relation to food competition. Mar. Biol. 156, $355-372$.

Uddin, M.J., Yang, H.-S., Choi, K.-S., 2010. Seasonal changes in Perkinsus olseni infection and gametogenesis in Manila clam, Ruditapes philippinarum, from Seonjaedo Island in Incheon, off the west coast of Korea. J. World Aquac. Soc. 41, 93-101.

Velez, C., Figueira, E., Soares, A., Freitas, R., 2015. Spatial distribution and bioaccumulation patterns in three clam populations from a low contaminated ecosystem. Estuar. Coast. Shelf Sci. 155, 114-125.

Verlecar, X.N., Pereira, N., Desai, S.R., Jena, K.B., Snigdha, 2006. Marine pollution detection through biomarkers in marine bivalves. Current Sci. 91, 1153-1157.

Villalba, A., Casas, S.M., López, C., Carballal, M.J., 2005. Study of perkinsiosis in the carpet shell clam Tapes decussatus in Galicia (NW Spain). II. Temporal pattern of disease dynamics and association with clam mortality. Dis. Aquat. Org. 65, 257-267.

Waki, T., Shimokawa, J., Watanabe, S., Yoshinaga, T., Ogawa, K., 2012. Experimental challenges of wild Manila clams with Perkinsus species isolated from naturally infected wild Manila clams. J. Invertebrate Pathol. 111, 50-55.

Walne, P.R., Mann, R., 1975. Growth and biogeochemical composition in Ostrea edulis and Crassostrea gigas, in: Barnes, H. (Ed.), 9th European Marine Biology Symposium. Aberdeen University Press, pp. 587-607. 
Wang, X., Zhou, Y., Yang, H., Wang, Q., Liu, S., 2010. Investigation of heavy metals in sediments and Manila clams Ruditapes philippinarum from Jiaozhou Bay, China. Env. Monit. Assess. 170, 631-643.

Watanabe, S., Katayama, S., Kodama, M., Cho, N., Nakata, K., Fukuda, M., 2009. Smallscale variation in feeding environments for the Manila clam Ruditapes philippinarum in a tidal in Tokyo Bay. Fish. Sci. 75, 937-945.

Watanabe, S., S. Katayama., 2010. Relationships among shell shape, shell growth rate, and nutritional condition in the Manila clam (Ruditapes philippinarum) in Japan. J. Shellfish Res. 29, 353-359.

Yang, H.-S., Park, K.-I., Donaghy, L., Adhya, M., Choi, K.-S., 2012. Temporal variation of Perkinsus olseni infection intensity in the Manila clam Ruditapes philippinarum in Gomso Bay, off the west coast of Korea. J. Shellfish Res. 31, 685-690.

Yoshinaga, T., Watanabe, S., Waki, T., Aoki, S., Ogawa, K., 2010. Influence of Perkinsus infection on the physiology and behavior of adult Manila clam Ruditapes philippinarum. Fish Pathol. 45, 151-157.

Zilber-Rosenberg, I., Rosenberg, E. (2008). Role of microorganisms in the evolution of animals and plants: the hologenome theory of evolution. FEMS Microbiol. Rev. 32, $723-$ 735. 


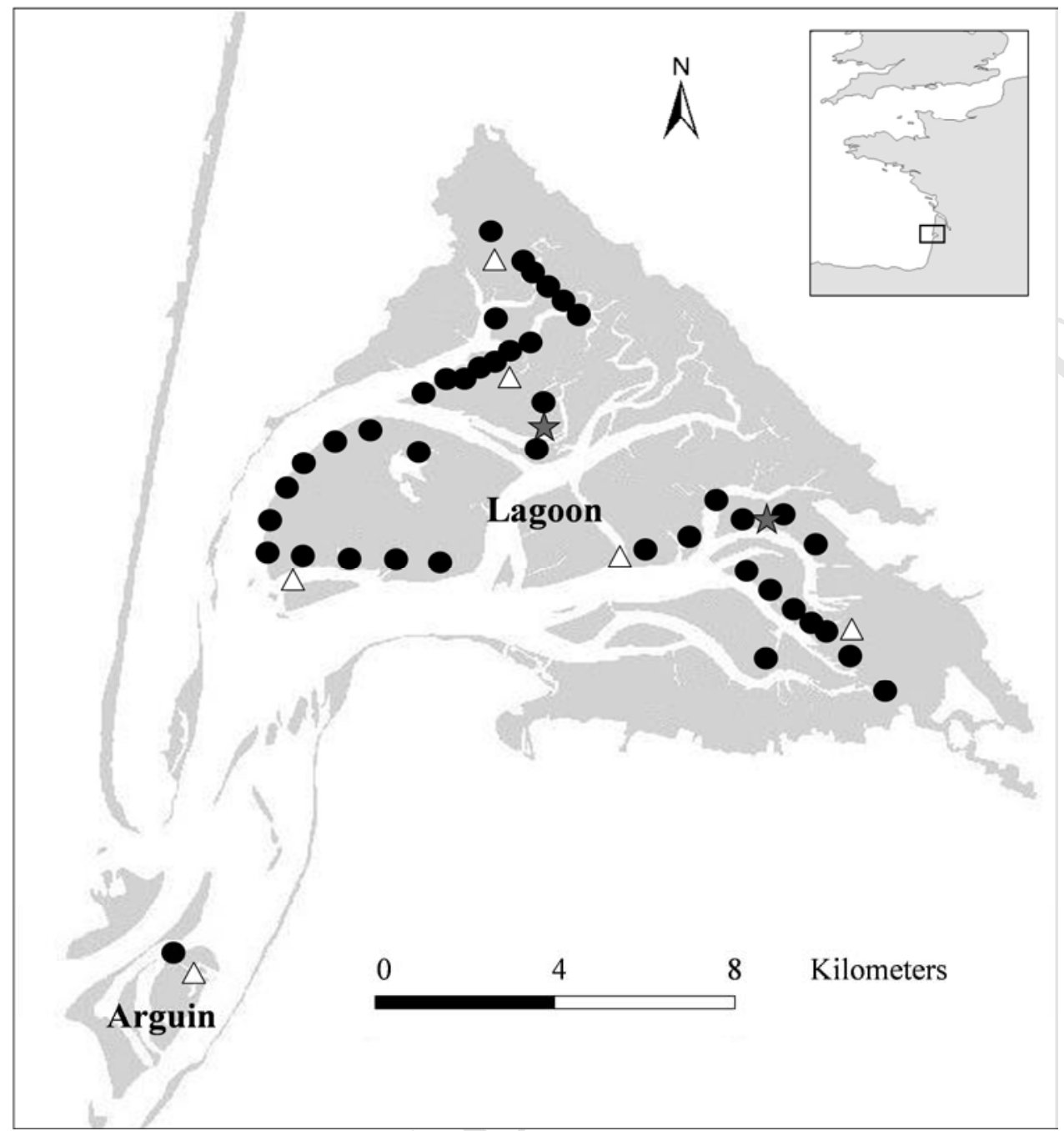

Fig. 1. Arcachon Bay map with the sampling sites indicated inside the lagoon and at Arguin: $\triangle$ sampling sites for trace elements in 2010, 2011 and 2012 (this study), sampling sites for perkinsosis measurements in 2004 (IFREMER, 2005), 2006, 2007 (Dang et al., 2010a, 2013) and 2009 (Binias et al., 2014a), and $\star$ sampling sites for total hemocyte count (THC) determinations in 2007, 2008 (de Montaudouin et al. 2010) and 2012 (this study). 


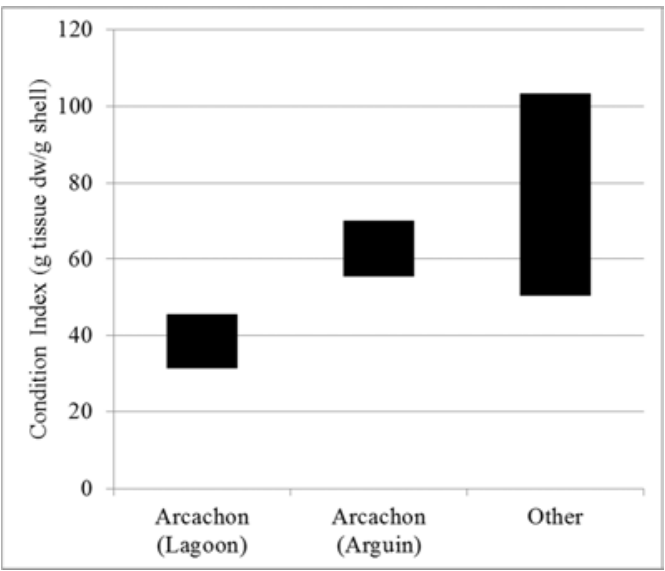

Fig. 2. R. philippinarum - Mean range of condition index in Arcachon lagoon (main habitat of the Asari clam), Arguin (out the lagoon) and other sites in France, Ireland, Italy, Portugal and Korea (see Table 1). 


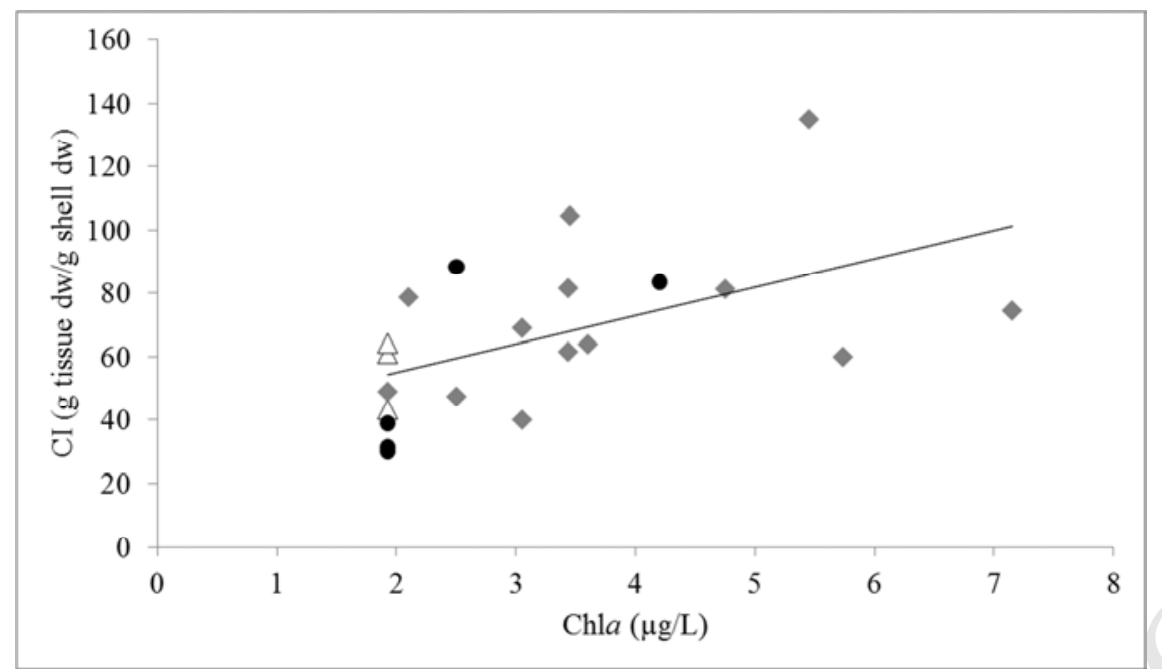

Fig. 3. Relationship between the median condition index (CI) and the median chlorophyll a concentration (in $\mu \mathrm{g}$ of $\mathrm{Chl}$ a per $\mathrm{L}$ ) in Arcachon lagoon, $\triangle$ Arguin and $\downarrow$ other sites from the literature in France, Ireland, Italy, Portugal and Korea. 


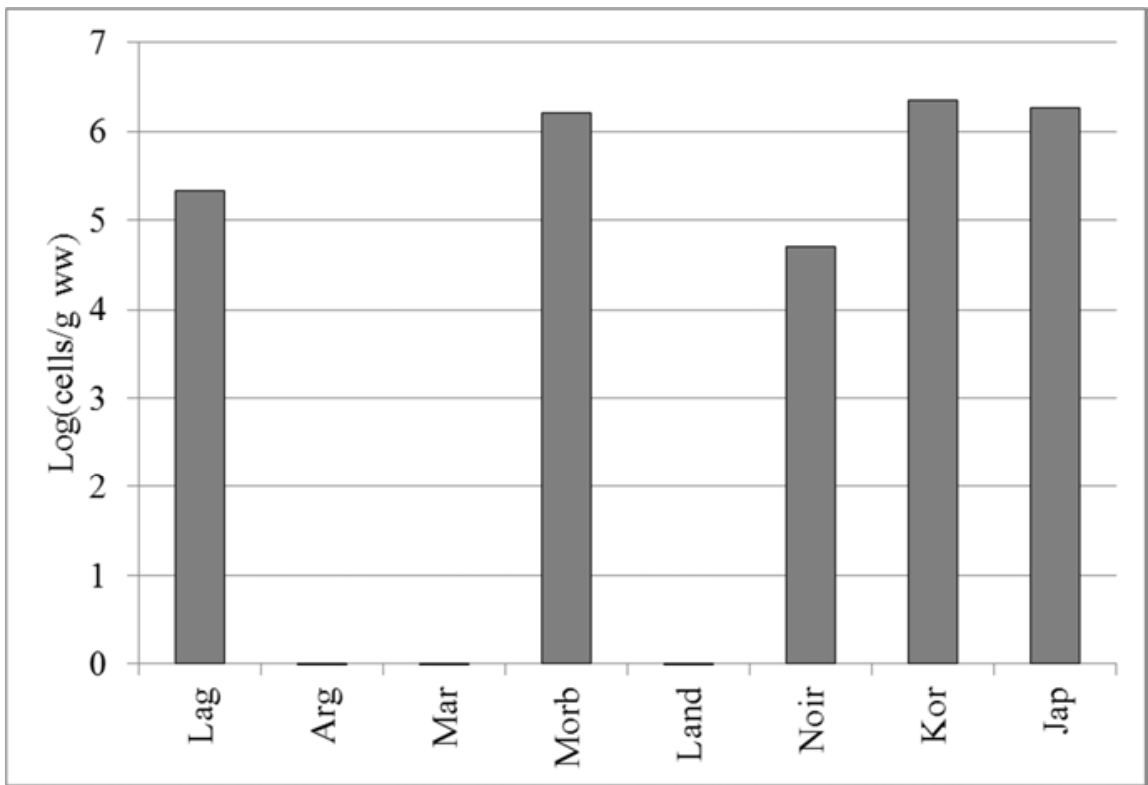

Fig. 4. Infection abundance range (cell $\mathrm{g}^{-1} \mathrm{ww}$ ) in logarithmic scale of Perkinsus in clams from France: Arcachon lagoon (Lag), Arguin (Arg), Marennes-Oléron (Mar), Morbihan (Morb), Landéda (Land), Noirmoutier (Noir), Korea (Kor) and Japan (Jap). 


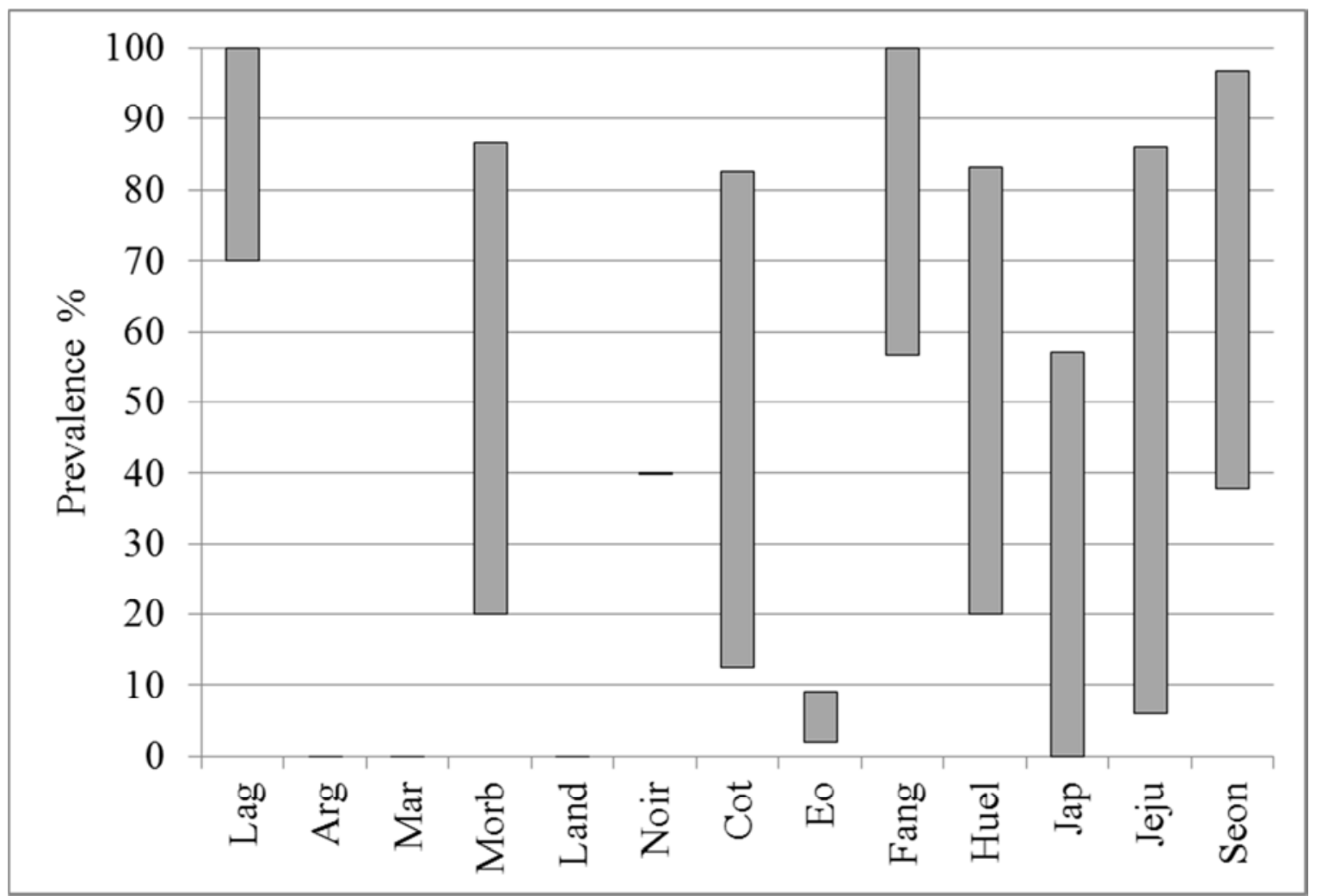

Fig. 5. Infection prevalence range $(\%)$ of perkinsosis in clams from France: Arcachon lagoon (Lag), Arguin (Arg), Marennes-Oléron (Mar), Morbihan (Morb), Landéda (Land), Noirmoutier (Noir), Cotentin (Cot), Spain: Eo estuary (Eo), Fangar Bay (Fang), Huelva (Huel), Japan (Jap), and Korea: Jeju Island (Jeju), Seonjaedo Island (Seon). 


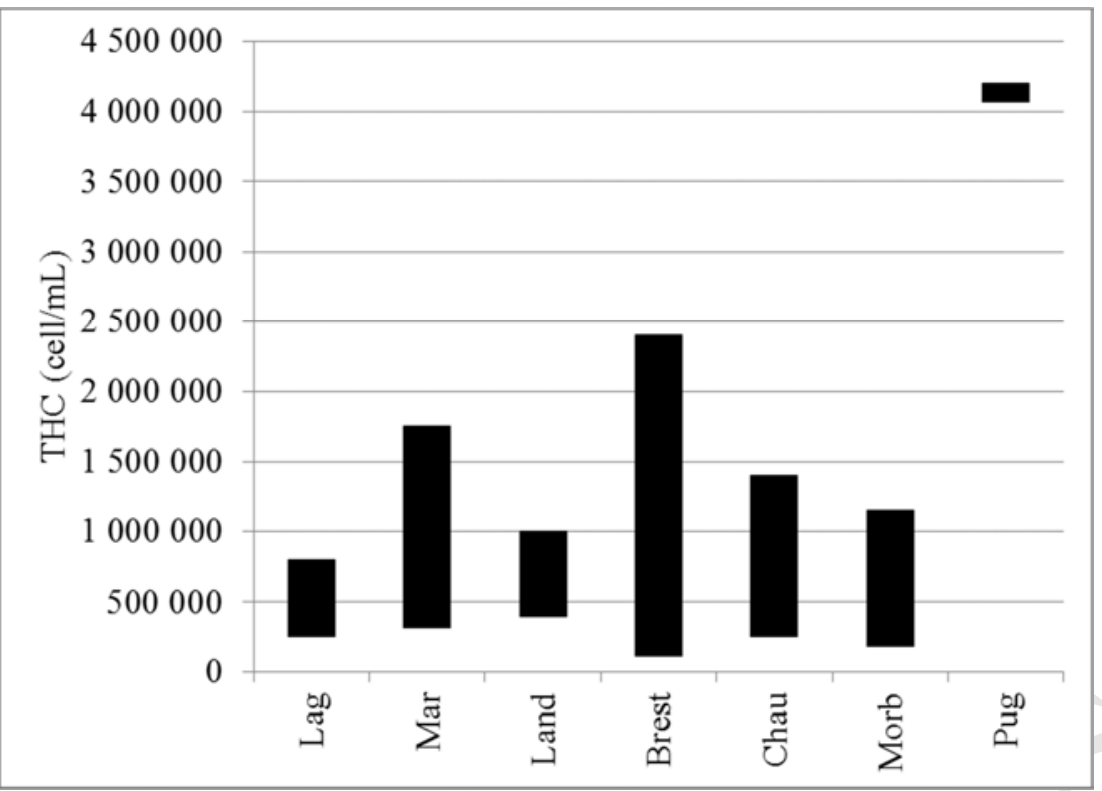

Fig. 6. Total hemocyte count (THC, cell $\mathrm{mL}^{-1}$ ) in clams from France: Arcachon lagoon (Lag), Marennes-Oléron (Mar), Landéda (Land), Bay of Brest (Brest), Chausey Island (Chau), Morbihan (Morb), and USA: Southern Puget Sound (Pug). 


\section{Table 1}

References used from the literature to compare Asari clam ( $R$. philippinarum) trace element concentrations, perkinsosis abundance and prevalence, total hemocyte count (THC), condition index (CI) and phytoplankton biomass through chlorophyll a concentrations (Chl a) between Arcachon Bay and different sites in the world.

\begin{tabular}{llllll}
\hline Sites & Trace elements & Perkinsosis & THC & CI & Chl a \\
\hline Arcachon & & $7,8,14,15,19,30,34$ & 8,19 & $8,14,16,30$ & 25,44 \\
France & 5 & $19,24,29,30,34$ & $1,2,13,19,20,24,45$ & $6,17,26,30,45$ & $3,10,22,31,32,44$ \\
Ireland & & & 21 & 18 \\
Italy & $35,42,46$ & & 9,35 & $9,27,43$ \\
Portugal & & $12,23,37$ & 48 & 35 \\
Spain & & & & \\
USA & & & & \\
China & 39,49 & $38,40,41,47,50$ & & 4 & \\
Korea & 33 & 11,28 & & \\
Japan & & & & & \\
\hline
\end{tabular}

1 - Allam et al., 2000; 2 -Allam et al., 2001; 3 - Bacher and Goulletquer, 1989; 4 - Baek et al., 2014; 5 - Baudrimont et al., $2005 ; 6$ - Beninger and Lucas, 1984; 7 - Binias et al., 2014a; 8 - Binias et al., 2014b; 9 - Boscolo et al., 2003; 10 - Bruchon et al., 2008; 11 - Choi et al., $2002 ; 12$ - Cigarría et al., $1997 ; 13$ - da Silva et al., $2008 ; 14$ Dang et al., 2013; 15 - Dang et al., 2010a; 16 - Dang et al., 2010b; 17 - Daou and Goulletquer, 1988; 18 - Darecki et al., 2003 ; 19 - de Montaudouin et al., $2010 ; 20$ Delaporte et al., 2003; 21 - Drummond et al., 2006; 22 - Dutertre et al., 2013; 23 - Elandalloussi et al., 2008; 24 - Flye-Sainte-Marie et al., 2009; 25 - Glé, 2007; 26 Goulletquer, 1989; 27 - Gunatilaka et al., 2009; 28 - Hamaguchi et al. 1998; 29 - Hégaret et al., 2007; 30 - IFREMER, 2005; 31 - IFREMER, 2011; 32 - IFREMER, 2013; 33 - Ji et al., 2006; 34 - Lassalle et al., 2007; 35 - Lopes et al., 2007; 36 - Moschino et al., 2012; 37 - Navas et al., $1992 ; 38$ - Ngo and Choi, $2004 ; 39$ - Pan and Wang, 2011; 40 - Park and Choi, 2001; 41 - Park et al., 2006; 42 - Sfriso et al., 2008; 43 - Sfriso et al., 2003; 44 - SOMLIT, $2014 ; 45$ - Soudant et al., $2004 ; 46$ - Trombini et al., 2003; 47 - Uddin et al., 2010; 48 - Velez et al. 2015; 49 - Wang et al., $2010 ; \mathbf{5 0}$ - Yang et al., 2012. 


\section{Table 2}

Trace element concentration ranges (minima and maxima means in $\mu \mathrm{g} \mathrm{g}^{-1} \mathrm{dw}$ ) in Asari clams from Arcachon lagoon and Arguin (this study) and other sites obtained from the literature in France, Italy, China and Korea. Details about reference numbers are indicated in Table 1.

\begin{tabular}{|c|c|c|c|c|c|c|c|c|c|c|c|c|c|}
\hline Location & $\operatorname{Ref}$ & $\mathrm{Ag}$ & $\mathrm{Al}$ & As & $\mathrm{Cd}$ & Co & $\mathrm{Cr}$ & $\mathrm{Cu}$ & $\mathrm{Hg}$ & $\mathrm{Mn}$ & $\mathrm{Ni}$ & $\mathrm{Pb}$ & $\mathrm{Zn}$ \\
\hline Arcachon (lagoon) & & $0.6-4.2$ & $98.0-550.0$ & $30.0-60.5$ & $0.2-0.7$ & $2.5-4.0$ & $17.5-97.0$ & $7.0-15.0$ & $0.4-1.2$ & $7.0-30.3$ & 8.3-71.0 & $0.9-4.0$ & $76.5-86.5$ \\
\hline Arcachon (Arguin) & & $1.6-5.3$ & $30.0-200.0$ & $27.0-30.0$ & $0.1-0.2$ & $1.8-2.0$ & $20.0-40.0$ & $5.0-8.0$ & $0.2-0.3$ & $9.0-10.0$ & $3.0-35.0$ & $0.4-3.3$ & $60.0-80.0$ \\
\hline \multicolumn{14}{|l|}{ France } \\
\hline Gironde estuary & 5 & & & & 0.1 & & & 20.0 & 0.10 & & & & 90.0 \\
\hline \multicolumn{14}{|l|}{ Italy } \\
\hline Marano lagoon & 42 & & & $42.8-64.0$ & $0.3-0.4$ & $1.5-2.7$ & $3.1-4.4$ & $8.4-13.7$ & $1.4-2.0$ & $13.1-25.8$ & $3.0-8.4$ & $0.5-1.2$ & $68.7-81.7$ \\
\hline Venice lagoon & 36,42 & & & $14.6-30.1$ & $0.4-1.7$ & $0.8-2.4$ & $1.2-2.6$ & $7.9-21.5$ & $0.2-0.6$ & $8.0-19.0$ & $1.1-9.2$ & $0.4-3.2$ & $88.7-186.5$ \\
\hline Pialassa Baiona & 46 & & & & & & & & $0.3-0.6$ & & & & \\
\hline \multicolumn{14}{|l|}{ China } \\
\hline Jiaozhou Bay & 49 & & & & & & $15.6-25.3$ & $7.4-13.7$ & & $28.2-45.9$ & $18.0-26.2$ & $2.1-7.3$ & $70.3-80.8$ \\
\hline Clear Water Bay & 39 & & & & & & & & $0.03-0.11$ & & & & \\
\hline \multicolumn{14}{|l|}{ Korea } \\
\hline Kyeonggi bay & 33 & & & & $0.5-2.2$ & $0.6-8.6$ & $0.6-2.4$ & $5.5-14.3$ & & $20.5-177.0$ & $2.7-33.5$ & $0.3-1.7$ & $64.7-162.0$ \\
\hline
\end{tabular}




\section{Table 3}

Trace element concentration ranges (minima and maxima means in $\mu \mathrm{g} \mathrm{g}^{-1} \mathrm{dw}$ ) in sediments from Arcachon lagoon, Arguin (this study) and other sites obtained from the literature in France, Italy, China and Korea. Details about reference numbers are indicated in Table 1.

\begin{tabular}{|c|c|c|c|c|c|c|c|c|}
\hline Location & $\operatorname{Ref}$ & As & $\mathrm{Co}$ & $\mathrm{Cu}$ & Mn & $\mathrm{Ni}$ & $\mathrm{Pb}$ & $\mathrm{Zn}$ \\
\hline Arcachon (lagoon) & & $9.7-26.0$ & $4.2-9.5$ & $8.9-26.0$ & $85.2-214.3$ & $9.9-22.7$ & $15.1-38.4$ & $63.5-146.5$ \\
\hline Arcachon (Arguin) & & $9.8-15.2$ & $0.6-0.8$ & $1.4-2.1$ & $14.0-19.3$ & $0.8-1.3$ & $1.0-2.4$ & $8.9-10.7$ \\
\hline \multicolumn{9}{|l|}{ France } \\
\hline Gironde estuary & 5 & & & $20.0-30.0$ & & & & \\
\hline \multicolumn{9}{|l|}{ Italy } \\
\hline Marano lagoon & 42 & $4.0-6.6$ & & $2.7-4.2$ & $357.0-386.0$ & $18.6-26.3$ & $2.4-6.8$ & $4.1-26.7$ \\
\hline Venice lagoon & 36,42 & $5.7-20.8$ & $6.6-13.8$ & $6.3-58.0$ & $244.0-360.0$ & $18.7-46.6$ & $7.2-57.7$ & $41.7-391.5$ \\
\hline \multicolumn{9}{|l|}{ China } \\
\hline Jiaozhou Bay & 49 & & & $14.2-25.1$ & $407.5-564.9$ & $33.1-39.9$ & $12.9-21.9$ & $72.9-88.1$ \\
\hline \multicolumn{9}{|l|}{ Korea } \\
\hline Kyeonggi Bay & 33 & & $7.8-8.6$ & $8.4-9.3$ & $450.0-842.0$ & $12.2-17.1$ & $12.7-13.7$ & $47.7-56.8$ \\
\hline
\end{tabular}

